УДК: $316.472: 615.851$

DOI: $10.26565 / 2410-1249-2019-12-06$

\title{
PSYCHOLOGICAL FACTORS OF LIFE SCRIPT' CONSTRUCTING AT MODERN YOUNG WOMEN
}

\author{
Olesya Zubenko \\ V.N. Karazin Kharkiv National University \\ m. Svobody 6, Kharkov, 61022, Ukraine \\ E-mail: olesyazubenko.kh@gmail.com,https://orcid.org/0000-0002-6611-5084
}

\begin{abstract}
The work is devoted to the problem of the personality's life script constructing. Understanding of the personality from the point of view of integrative categories, such as "lifestyle", "life script is basic ideology or present investigation. These psychological phenomena describe not only the events of a particular person's life, but also make it possible to understand one's personal qualities, self-image, patterns of behavior and relationship-building as a coherent system of interaction between the individual and the world. The psychological factors that influence the life script's construction are analyzed and summarized: the critical period of personality's development influence and the events that took place in it; the influence of family and parenting; traumatic or significant life events; transgenerational factors. An empirical study is aimed at investigating early traumatic personality experiences as a factor in the formation of a life script. The study was conducted on a student sample of young women. Early traumatic experience was operationalized through the concept of J. Young's early maladaptive schemes and the application of the "Diagnosis of early maladaptive schemes" technique. The life script is revealed through the use of the life position questionnaire, which allows one of four types of script to be established: "Winner", "Loser", "Pessimist", "Inferiority Complex". The article shows that certain types of life scripts of modern young women reveal correlative relationships with components of early traumatic personality experiences that crystallize as early maladaptive schemes. On this basis, the psychological characteristics of the basis of each four types of scripts are presented: "Winner", "Losers", "Pessimist", "Inferiority Complex ". The psychological foundations of constructive and non-constructive scripts based on early maladaptive schemes related to their construction are revealed.
\end{abstract}

KEY WORDS: life script, lifestyle, early maladaptive schemes, personality, traumatic life events, parental attitudes, young women, psychotherapy.

Problem statement. For a long period, there was a tendency in psychology to analyze the variety of manifestations of mental life from the standpoint of describing certain characteristics of personality, namely: character, temperament, personality orientation, life sense, etc. This approach often leads to creation of an isolated, unsystematic view of the individual's nature and builds disparate and disordered "map" of human life. The vector of modern psychological research is aimed at creating a systematic view of the world in which there is a person, peculiarities of its functioning and development. One of the most promising ways to achieve this goal is the development of analyzing ideas and ideas of disclosing human understanding in terms of integrative categories, such as "lifestyle", "life script", that describes not only the events of a particular person's life, but also allows to combine personal qualities, self-image, behaviors and relationships in a holistic system of personality's interaction with the world. In this approach, the aspects related to the understanding of the person as the subject of one's life are largely embodied, emphasized "authorship" in relation to one's life, possibility of "reconstruction", change of life path (Mizinova, 2013; Vereshchagina, Gagulaeva, 2016; Kostromina, Grishina, Zinovjeva, Moskovicheva, 2018).

The study of the mechanisms and factors of constructing one's own life is becoming more actual in connection with the active transformation observed in the contemporary socio-cultural space of Ukraine. The major psychological vectors of this transformation reflect the loss of the mature personality's values among young people, what evidenced by the widespread phenomenon of the devaluation of adulthood, infantilization, "changeager", or youth lifestyles, narcissism and scarcity of semantic existential (Kocharian, Barinova, Zubenko, 2017). This is in line with the opinion of D. Stevens, who believes that many adults have stopped at a lower level in their development than their age requires (Psychology from Birth to Death. edited byRean, 2005). Therefore, the search and disclosure of the psychological units that crystallize the life script of the person, seems to be perspective not only 
in terms of identifying the mechanisms of constructing the life by the individual, but also - the possibilities of correction and achievement of psychological well-being in relations with oneself and significant environment.

Problem analysis. Today, following the evolution of ideas about the life script, we can distinguish various aspects of its definition (Mizinova, 2013; Vereshchagina, Gagulaeva, 2016; Kostromina, Grishina, Zinovjeva, Moskovicheva, 2018):

-as a current life plan, characterized by unconsciousness and formed in early childhood under the influence of parents, according to which people structure longer periods of time and even their entire lives;

- the process of ordering the experience, accompanied by the symbolization of subjective experiences;

- the process of structuring the personal event picture of life, aimed at its self-improvement through creativity;

- automated event circuits - "scripts", including ideas about organized sequences of events, aim of behavior, possible role positions;

- individual or personal life in its dynamics;

- a semantic system that depends not only on socialization influence but also

built by the personality itself.

For the first time, the concept of a life script was proposed by Eric Bern and his colleagues, in particular, by Claude Steiner (Bern, 2016, Joines, Stewart, 1999). Today the concept of the script together with the ego-state model, is the central idea of transactional analysis.

E. Berne defined the script as an "unconscious life plan" or more precisely a "life plan based on childhood illusions and parental programming" (Bern, 2016, p. 37). His theory expresses the idea that a child draws up a plan of his life, and not just forms the basic outlook on life. This plan is in the form of a drama with clearly marked start, middle and end. That means E. Berne actually identifies the life scenario of a person with his fate.

Subsequently, the content of the life script concept, proposed by E. Bern, begins to be revised, in particular by abandoning its narrowly psychoanalytic interpretation. So, the dynamics of views on the life scenario are presented in the work "Life Scripts: Transactional Analysis of Unconscious Relationship Patterns" (Life Scripts: A transactional analysis of unconscious relational patterns, 2010). The main tendency is the transition from the description of the scenario determined by the parents to its socially constructivist understanding. The basis for this is a therapeutic practice that demonstrates the relationship between scenario formation and relationship therapy. Script theories based on descriptions of cognitive and other intrapsychic processes lead to the assumption that scenario change is possible through internal changes in habitual patterns of relationships. Accordingly, if the relationship forms a script, they can also transform it (Life Scripts: A transactional analysis of unconscious relational patterns, 2010, p. 77). The proof of this is the changes in life associated with the relationships formed in the course of psychotherapy.

The psychological literature analysis allows us to generalize the understanding of the psychological factors that influence the construction of one's life script. Among the most significant scientists point out the impact of the critical period (as the period of personal development) and the events that took place in it; the influence of the immediate environment (family); traumatic or significant life events; transgenerational factor; subjective factors (human decisions).

According to E. Bern's concept of transactional analysis, family and subjective factors are mainly influenced by the formation of life script: 1) parental direction (a message from parents about what to do or not to do, as well as thoughts and guidance about people and the whole world); 2) the level of personal development (first of all, it is a matter of building an effective life script: the level of intellectual development, personal competence, orientation to achieving life goals, ability to emotional manifestations, level of personal maturity); 3) decisions that were in childhood most often occur under the unconscious "pressure" of parental messages (it is a question of modeling one's own behavior); 4) true "involvement" in some particular method that carries success or failure (Bern, 2016; Makarov, Makarova, 2002).

Developing these ideas, Stan Woollems (cited by Craig, 2005; Kupchenko, 2002) has identified two key features of life script's formation: 1 . Scripts are the best strategy for a child to survive in a world that often seems hostile to him or even life-threatening; 2. script decisions are made in accordance to the emotions of the child and his or her ability to test reality. 
Based on these influences, it becomes possible to form one (preferred) of the four main types of life script: 1) "I" am good, "All of them are good, life is good" - "Winner" script; 2) "I" am bad, "they are bad, life is bad" - script of "Loser", failure; 3) "I" am good, but "they are bad, life is bad" - the script of "Pessimist"; 4) "I" am bad, and "they are good" is a script of "Inferiority Complex" (Joines, Stewart, 1996).

There is a traditional "psychoanalytic" ideology regarding the crucial role of the early childhood period (up to 5-6 years) regarding the understanding of the critical periods of life script formation in the framework of transactional analysis. The life plan is formed on the basis of early life events, impressions that correlate with any familiar child script, borrowed from tales, stories, myths, legends, pictures. That is, the script is fully formed and launched at childhood. But its addition and modification is possible and later. In the adolescent life script goes through a stage of refinement, acquires a certain structure. Later, it is used by an adult to structure the living space, optimal interaction with the outside world and to predict the near and distant future.

Actually, in the theory of A. Adler (1997) considered a number of family factors that influence the construction of lifestyle. Certainly, the critical period in the formation of life style is the period of early childhood. Such factors are: the order of birth of the child in the family; the influence of parents (their actions, evaluations, emotional support or deprivation); the influence of grandparents and the presence of siblings; acceptance by the child of his name; accidental extreme events (concerns mostly adults). As the engines of personality development, A. Adler (1997) discusses 1) sense of community; 2) feelings of inferiority or inadequacy; and 3) desire for individual importance (or self-importance). The peculiarities of the interaction of these factors of personality development are reflected in the lifestyle of a person.

Transgenerational factors of life script construction are the subject of research in the works of A.A. Schützenberger, F. Dolto, N. Abraham, I. Buzormeni-Nad, who study the complex problem of transgenerational transmission of unresolved conflict, family secrets, premature deaths and the choice of profession, which are in fact part of the life plan of the father's personality (Schützenberger, 2005). Integrating different views on the problem of transgenerational transmission and conducting our own studies (using the genosociogram method), A.A. Schutzenberger concludes that the attitude of a person to life, personal successes and failures, the choice of a profession, the choice of a partner and even the age at which we decide to get marriage or childbearing may be caused by events that have occurred in the family several generations before the birth of the person.

The analysis shows that the views of different scientists are similar in the interpretation of the role of critical periods for the formation of personal lifestyles, as well as in understanding the main factors of influence. In fact, there is talk of events the traumatic nature of events that makes these events or related people meaningful and "fateful" in the way of becoming a lifestyle. For the in-depth disclosure of precisely the mechanisms that explain the role of early childhood or other critical periods of personality development, life events, and significant life-shaping individuals, we set out the aim of our research to investigate the impact of early traumatic experiences on a life- script formation of contemporary young women.

The following methods were used for the study:

1) Diagnosis of early maladaptive scheme (J. Young; adaptation by P.M. Kasyanik, E.V. Romanova) to determine early traumatic experiences. This technique is a questionnaire that is based on a presentation by J. Young (Handbook of Schema Therapy, 2012) regarding early maladaptive scheme (EMS). This term refers a stable set of reactions, ideas, emotions that were formed in early childhood under the influence of any adverse factors in the immediate environment. EMS are stable structures that influence the actual perception of the world and the management of one's own activities. J. Young was allocated 18 EMS, which are divided into five large groups (domains), which are related on the satisfaction of various basic needs: "Disruption of communication and rejection"; "Violated autonomy". "Targeting others"; "Violation of borders"; "Excessive vigilance and prohibitions."

2) life position questionnaire for the diagnosis of the preferred type of personality's life script. This technique was developed in the concept of E. Bern's life script. As a result, one of the four possible types of life scenario is diagnosed: "Winner"; "Loser" ("losers"); "Pessimist"; "Inferiority Complex".

Kendall correlation analysis was applied for mathematical and statistical processing. 
The research sample included 105 women aged 19 to 23 who are students of higher education institutions in Kharkiv.

Research results. The results show that there are a number of correlation connections that reach statistical significance $(\mathrm{p}<0.05)$, which form the types of life script with the EMS scales. The results for clarity are shown in the form of drawings (Fig. 1-4).

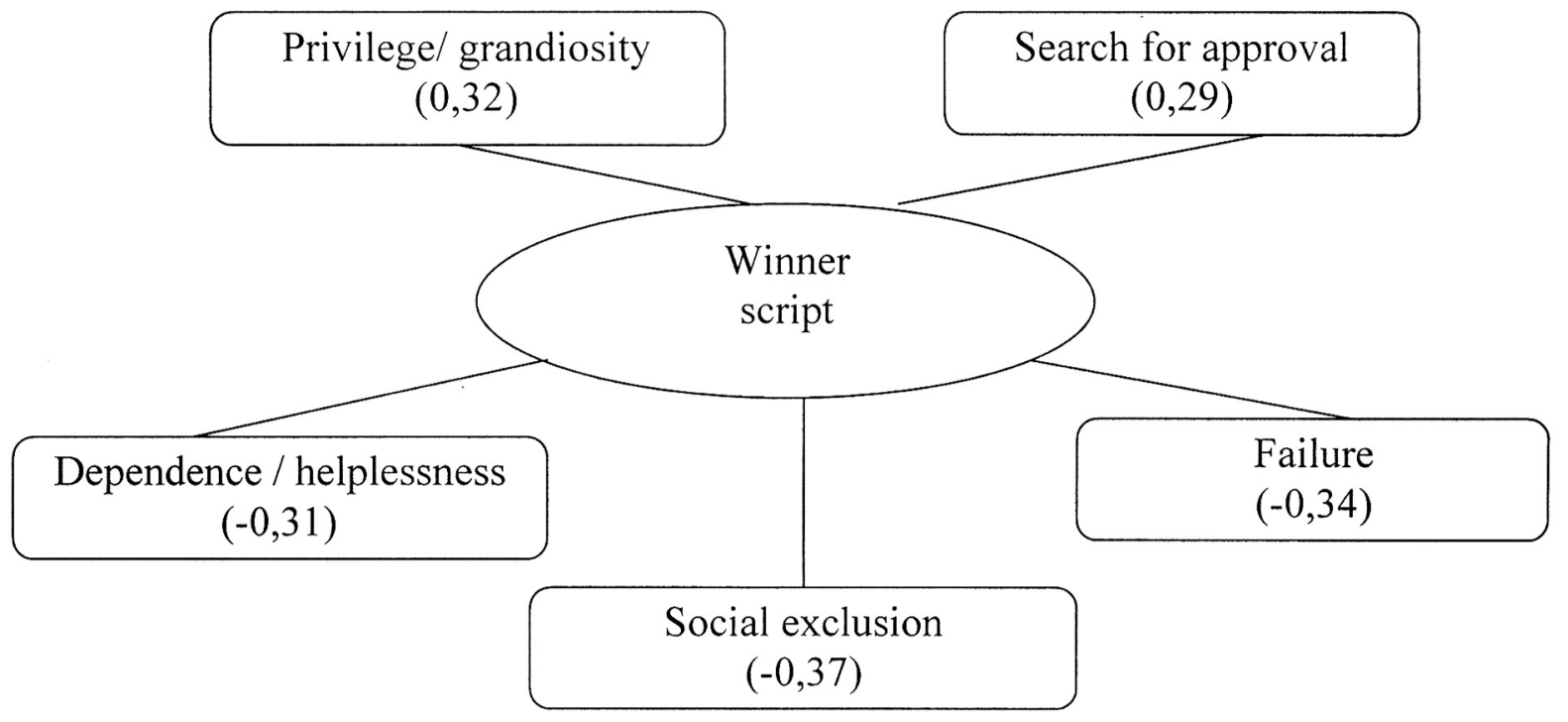

Figure 1. Correlation connection of the "Winner" script with early maladaptative scheme.

According to the above data, the "Winner "script has both positives with the "Border Crossing" and "Targeting domain", as well as negative links with the domein EMS "Autonomy Disrupting" and "Disrupting domains". Positives - formed with the following scales of the EMS methodology: privilege / grandiosity (0.32); seeking approval (0.29). Negative links to the dependency / helplessness scales $(-0.31)$ failure $(-0.34)$, social alienation (-0.37) were also detected. The "Winner" script usually is considered as the most adaptable and mature type, reflecting a positive attitude towards private "Self" and the world around me. However, we see that this script contains immature elements that are narcissistic traits of personality (focus on special rights and seeking approval). It is also based on mature components: social orientation, selfbelief, and stability of self-identity, confirming links to low levels of social exclusion, dependence, and failure.

The following figure illustrates the EMS that underlies the "Loser" script.

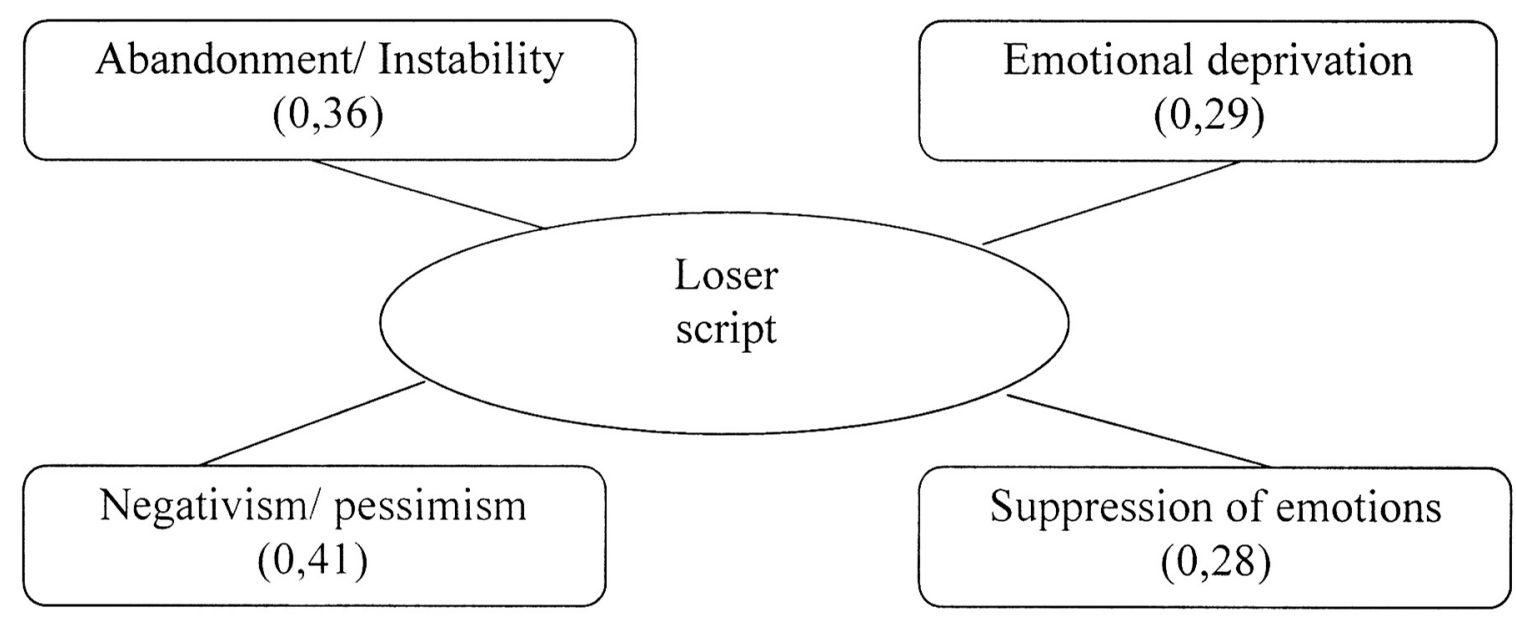

Figure 2. Correlation links of the "Loser" script with early maladaptive schemes.

The "Loser" script has links to two EMS domains: "Disruptions and Rejections" and "Excessive Vigilance and Prohibitions." All found out correlation relationships are positive and are related to the following scales: abandonment/ instability (0.36); emotional deprivation (0.29), 
negativism/ pessimism (0.41); depression / suppression of emotions $(0,28)$. That is, the basis of this scenario is to experience the rejection and suppression of basic needs.

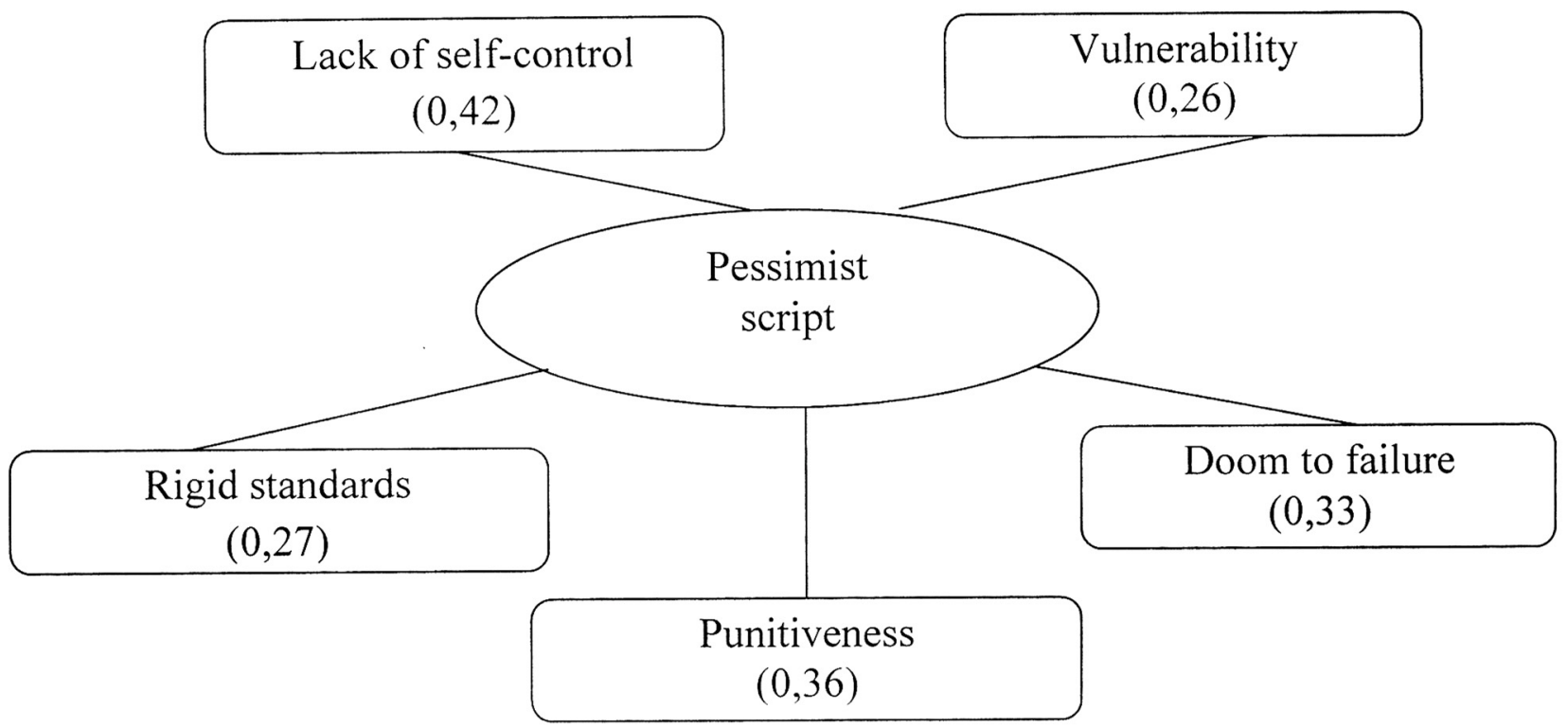

Figure 3. Correlation of the "Pessimist" script with early maladaptive schemes.

The "Pessimist" script correlates positively with EMS from "Violated autonomy", "Border violation" and "Excessive vigilance and prohibitions" domains. Positive associations were found out with indicators such as lack of selfcontrol / self-discipline (0.42); vulnerability / tendency to physical harm or illness $(0.26)$; doom to failure (0.33); inflated requirements for self / rigid standards (0.27); punitiveness / passivity (0.36). The results indicate that there is a foundation in the form of personality boundaries and autonomy deficits.

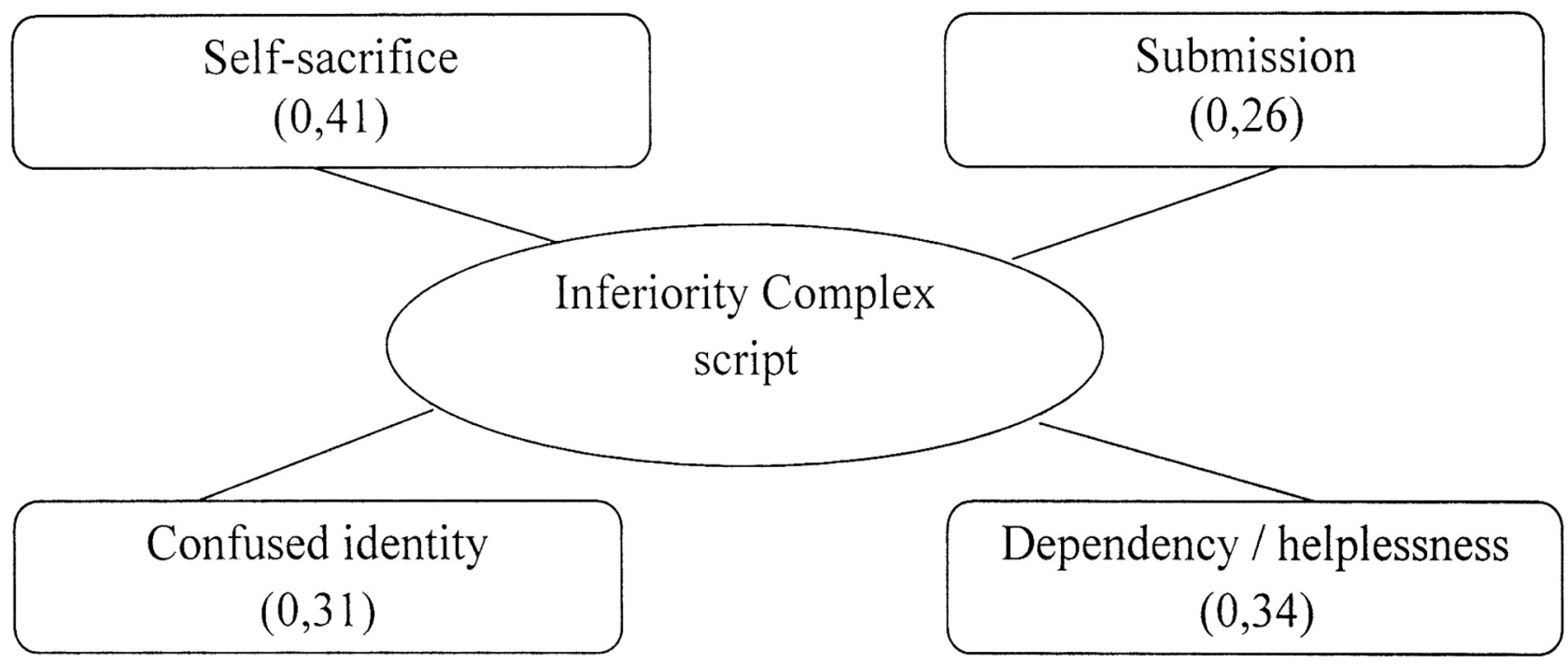

Figure 4. Correlation links of the "Inferiority Complex" script with early maladaptive schemes.

The "Inferiority Complex" script has a positive relationship with the "Orientation on others" domain and the "Autonomy violated" domain. From Figure 4 we can see that there are links to the scales: selfsacrifice (0.41); obedience / submission (0.26); confused identity / undeveloped I am (0.31); dependency / helplessness (0.34). We see that the basis of this scenario is formed by the frustration of the need for self-respect and self-importance.

All of the identified connections were obtained from the female sample and represent the stable model of the female script. In fact, "Winner" is a 
script of a woman with narcissistic traits and an active social position. "Loser" reflects the behaviors of an abandoned woman who does not feel her own needs. A "Pessimist" is a woman whose personality is formed in a situation of high demands and deprivation of autonomy, such that she does not feel her own rights. And a woman with an inferiority complex has a victim behavior model.

From the results obtained, it is clear that early maladaptive schemas, which include perceptions of a person about himself, the world, and other people, play an important role in the acquisition and interpretation of life experience. The revealed links indicate that EMS are inflexible mechanisms that are capable of self-support and that form a person's ability to display only relevant scheme information, limit its behavior, and, in general, form a scenario of a person's life that may even reduce social adaptation. This aspect raises questions about the possibility of a life-cycle correction, since purposeful therapeutic work with EMS is a prerequisite for effective correction and change of the life script.

\section{Conclusions}

1. The life scripts of modern young women reveal relationships with the components of an early traumatic personality experience, which crystallizes as early maladaptive patterns.

2. The constructive variant of script - "Winner" (based on the model of E. Bern's script), demonstrates the existence of specific EMS, reflecting narcissistic personality traits and behaviors in combination with mature traits: social orientation and confidence.

3. Non-constructive scenarios - "Loser", "Pessimist" and "Inferiority Complex" - are based on EMS, reflecting violations of personality boundaries, lack of autonomy, traumatic experiences of abandonment and the impact of strict standards in education.

We consider the direction of research as a prospect for further work into other components of early traumatic experiences (cognitive, emotional, etc.) and their relation with life-cycle development in adulthood.

\section{REFERENCE}

Adler A. (1997). Наука жить [Science live]. Kyiv: PortRoyal. (in Russian)

Bern E. (2016). Игры, в которые играют люди. Люди, которые играют в игры [Games People Play. People who play games]. Moscow: EKSMO. (in Russian)
Bern Е. (1992). Трансакционный анализ и nсихотерапия [Transactional Analysis and Psychotherapy]. SanktPetersburg: Bratstvo. (in Russian)

Vereshchagina M.V., Gagulayeva A.A. (2016). Genderspecific representations of students about the life of. Modern problems of science and education, 1. Retrieved from: https://www.scienceeducation.ru/en/article/view?id=24138. (in Russian)

Joins V., Stuart J. (1999). Жизненные сценарии [Life scenarios]. Moscow: IP RAN. (in Russian)

Joins V., Stuart J. (1996). Современный транзактный анализ [Modern transactional analysis], SanktPetersburg: Social'no-psihologicheskij centr.

Kostromina S.N., Grishina N.V., Zinovieva E.V., Moskvicheva N.L. (2018) Жизненная модель как конструкт изучения жизненного сценария личности [Life model as a construct of studying the life scenario of a person]. Vestnik of Saint Petersburg University. Psychology. 8(4), 341-357, https://doi.org/10.21638/11701/spbu16.2018.403. (in Russian)

Kocharyan A.S., Barinova N.V., Zubenko O.M. (2017). Personal determinants of life style: psychological valeology. Psychological Counseling and Psychotherapy. 1(8), 6-15. https://doi.org/10.26565/2410-1249-2017-8-05 (in Russian)

Craig G. (2005). Психология развития [Developmental psychology]. $9^{\text {th }}$ edition, Sankt-Petersburg: Piter. (in Russian)

Kupchenko V.E. (2002). Типологии жизненных стратегий [Typologies of Life Strategies]. Актуальные проблемы современной психологии: Сборник научных трудов [Actual problems of modern psychology: Collection of scientific papers] (p. 28-34), L.I. Dementij (Ed.), Omsk: Izd. OmGU, (in Russian)

Makarov V.V., Makarova G.A. (2002). Транзактный анализ - восточная версия [Transactional Analysis - Eastern Version], Moscow: Akademicheskij Proekt, OPPL. (in Russian)

Mizinova I.A. (2013). Жизненный сиенарий личности: основные подходы к рассмотрению [Personality Life Scenario: Key Considerations]. Известия Сарат. университета. Серия. «Философия. Психология. Педагогика» [Izvestia Sarat. University. Series. "Philosophy. Psychology. Pedagogy"]. 13(4), 59-64. (in Russian)

A.A. Rean (Ed.). (2005). Психология человека от рождения до смерти [Human psychology from birth to death]. Sankt-Petersburg: Прайм-Evroznak. (in Russian)

Shutzenberger A.A. (2005). Синдром предков: Трансгенерационные связи, семейные тайны, синдром годовщины, передача травм и 
практическое использование геносоииограммы [Ancestral Syndrome: Transgenerational Relationships, Family Secrets, Anniversary Syndrome, Injury Transmission and Practical Use of the Genosociogram], Moscow: Izd-vo Instituta Psichoterapii. (in Russian)
Van Vreeswijk M., Broersen J., Nadort M, (Ed.). (2012). Handbook of Schema Therapy: Theory, Research and Practice, London: Wiley-Blackwell.

R.G. Erskine (Ed.). (2010). Life Scripts: A transactional analysis of unconscious relational patterns, London: Karnac Books.

\section{ПСИХОЛОГІЧНІ ЧИННИКИ КОНСТРУЮВАННЯ ЖИТТЕВОГО СЦЕНАРІЮ СУЧАСНИХ МОЛОДИХ ЖІНОК}

Зубенко О. М.

Харківський начіональний університет ім. В.Н. Каразіна м. Свободи 6, Харків, 61022, Україна

Роботу присвячено проблемі побудування життєвого сценарію особистості. Основною ідеологією, яку покладено в основу, $\epsilon$ розуміння людини з точки зору інтегративних категорій, накшталт «стиль життя», «життєвий сценарій». Ці психологічні феномени описують не тільки події життя конкретної людини, але й дозволяють зрозуміти особистісні якості, образ себе, моделі поведінки й побудування стосунків як цілісну систему взаємодії особистості зі світом. В роботі проаналізовано та узагальнено психологічні чинники, які впливають на побудування життєвого сценарію: вплив критичного періоду розвитку та подій, що у ньому відбувалися; вплив сім'ї та батьківських настанов; травматичні або значущі події життя; трансгенераційні чинники. Емпіричне дослідження спрямовано на вивчення раннього травматичного досвіду особистості як чиннику формування життєвого сценарію. Дослідження реалізовано на студентській вибірці молодих жінок. Ранній травматичний досвід операціоналізовано через концепцію ранніх дезадаптивних схем Дж. Янга та застосування методики «Діагностика ранніх дезадаптивних схем». Життєвий сценарій виявлено завдяки застосування опитувальника життєвої позиції, який дозволяє встановити один з чотирьох типів сценарію: «Переможець», «Невдаха»; «Песиміст»; «Комплекс неповноцінності». В роботі показано, що певні типи життєвих сценаріїв сучасних молодих жінок виявляють кореляційні взаємозв'язки із компонентами раннього травматичного досвіду особистості, який кристалізується у вигляді ранніх дезадаптивних схем. На цій основі надано психологічну характеристику базису кожного 3 чотирьох типів сценаріїв: «Переможця», «Невдахи», «Песиміста», «Комплексу неповноцінності». Розкрито психологічний фундамент конструктивних та неконструктивних сценаріїв на основі ранніх дезадаптивних схем, що пов’язані із їхнім побудуванням.

КЛЮЧОВІ СЛОВА: життєвий сценарій, стиль життя, ранні дезадаптивні схеми, особистість, травматичні події життя, батьківські настанови, молоді жінки, психотерапія.

\section{ПСИХОЛОГИЧЕСКИЕ ФАКТОРЫ КОНСТРУИРОВАНИЯ ЖИЗНЕННОГО СЦЕНАРИЯ У СОВРЕМЕННЫХ МОЛОДЫХ ЖЕНЩИН.}

Зубенко О. М.

Харьковский национальный университет им. В.Н. Каразина пл. Свободы 6, Харьков, 61022, Украина

Работа посвящена проблеме построения жизненного сценария личности. Основной идеологией, какая-нибудь положена в основу, является понимание человека с точки зрения интегративных категорий, таких как «стиль жизни», «жизненный сценарий». Эти психологические феномены описывают не только события жизни конкретного человека, но и позволяют понять личностные качества, образ себя, модели поведения и построения отношений как целостную систему взаимодействия личности с миром. В работе проанализированы и обобщены факторы, влияющие на построение жизненного сценария: влияние критического периода развития и событий, которые в нем происходили; влияние семьи и родительских установок; травматические или значимые события жизни; трансгенерационные факторы. Эмпирическое исследование направлено на изучение раннего травматического опыта личности как фактора формирования жизненного сценария. Исследование реализовано на студенческой выборке молодых женщин. Ранний травматический опыт операционализован через концепцию ранних дезадаптивных схем Дж.Янга и применения методики «Диагностика ранних дезадаптивных схем». Жизненный сценарий выявлен путем применения опросника жизненной позиции, который позволяет установить один из четырех типов сценария: «Победитель», «Неудачник»; «Пессимист»; «Комплекс неполноценности». В работе показано, что определенные типы жизненных сценариев современных молодых женщин обнаруживают корреляционные взаимосвязи с компонентами раннего травматического опыта личности, который кристаллизуется в виде ранних дезадаптивних схем. На этой основе предоставлено психологическую характеристику базиса каждого из четырех типов сценариев: «Победитель», «Неудачник», «Пессимист», «Комплекс неполноценности». Раскрыто психологический фундамент конструктивных и неконструктивных сценариев на основе ранних дезадаптивных схем, связанных с их построением.

КЛЮЧЕВЫЕ СЛОВА: жизненный сценарий, стиль жизни, ранние дезадаптивные схемы, личность, травматические события жизни, родительские установки, молодые женщины, психотерапия. 